\title{
ARTICLE
}

\section{The Will and Authority of the Security Council after Iraq}

\author{
NIGEL D. WHITE*
}

\begin{abstract}
One year after the invasion of Iraq, what lessons are to be drawn about the role of the Security Council in peace and security? This article looks at the issue by considering the nature of the Security Council in its dual functions as a forum for diplomacy and a corporate body for executive action. The idea of the Security Council's possessing a separate will in its executive function is developed. The article stresses the importance for the authority of the Council of that organ expressing its will within the legal parameters of the Charter and international law. It is argued that similar legal parameters are also applicable to the permanent members in exercising their power of veto and in interpreting resolutions. Further, when interpreting resolutions member states should not misconstrue the will of the Council. The Iraq crisis of 2003 raised all these issues and, further, necessitated a reappraisal of the rules of international law governing the use of force. This article considers the relationship between diminution in Council authority and erosion of the rules of the UN Charter governing the threat or use of force in international relations.
\end{abstract}

\section{Key words}

interpretation; legal personality; permanent membership; resolutions; Security Council functions; threat or use of force; veto

\section{INTRODUCTION}

Inis Claude, writing at the height of the Cold War, stated that

The Security Council has not developed significantly as a corporate entity, displaying an emergent will and purpose that can be identified with it as a collective organ ... ${ }^{\mathrm{I}}$

With the odd historical aberrations such as the Korean war, sanctions against Southern Rhodesia and an arms embargo against South Africa, the Cold War prevented the Security Council from developing a separate will through executive action. This, however, did not prevent the Council from functioning. As Inis Claude noted,

\footnotetext{
* $\quad$ Professor of International Organisations, School of Law, University of Nottingham. This article is based on papers given at the law faculties of Sheffield and Utrecht universities, Queen Mary and Westfield College, and the British Institute of International and Comparative Law.

I. Inis Claude, 'The Security Council', in E. Luard (ed.), The Evolution of International Organizations (I966), 68, at 88.
} 
the requirement of consensus among the five permanent members of the Council $\left(\mathrm{P}_{5}\right)$ meant that the Council was intended to perform both an executive and a diplomatic function:

The Council was designed to serve as an instrument of action whenever a unanimous vote of the great powers revealed the existence of a consensus, and a forum for negotiation whenever the use of the veto revealed the absence of a consensus. In the era of the Cold War, the Council has had more frequent occasion to function in the latter capacity than in the former. ${ }^{2}$

It will not be argued here that a Council with a separate will is essential to maintain the integrity of the UN Charter scheme for collective security, where the only recognized exceptions to the prohibition on the use of force are self-defence and Council-authorized military action. As Inis Claude noted, the presence of the veto meant that the Council was intended to perform both executive and diplomatic functions. Indeed, Claude claimed that the diplomatic function 'is of primary, not secondary, importance - and it is not a function on which the Council can merely "fall back", an alternative role which is available when action proves unattainable'. ${ }^{3}$ Thus the failure of the Council to perform its executive function did not unravel the Charter scheme during the Cold War. This is contrary to the contention that the ineffectiveness of the Council meant that the rules prohibiting the use of force were denuded, since states would have to step in to perform a collective security role. Such a role would breach the formal rules of the Charter, being taken neither in self-defence nor under the authority of the Council. ${ }^{4}$ Such arguments were driven by 'the American . . passion for making the United Nations an agency for action'. ${ }^{5}$ The fact is that the Charter scheme was created in the full knowledge that there was no guarantee that the Council would take action, ${ }^{6}$ hence the clear preservation of the inherent right of self-defence that could only be affected if and when the Council acted. ${ }^{7}$

Rather it is contended here that since the Council started to fulfil its potential and realize its separate will in the post-Cold War era, care must be taken to establish the extent of that will, for it cannot possibly be unlimited. Moreover, extra care must be taken accurately to understand the expression of that will. This article will focus on both of these issues by considering briefly the legal limits on the powers of the Council, and the little-discussed legal regime that can be applied to the permanent members. The argument will show that abuse of the law by the organ is far outweighed by the anti-legal practice of the permanent members when interpreting resolutions, casting vetoes, and abdicating their responsibilities for peace and security. Both abuse of the law by the organ and by the permanent

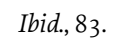

4. E.g. W. M. Reisman, 'Coercion and Self-determination: Construing Article 2(4)', (I984) 78 AJIL 642; A. C. Arend and R. J. Beck, International Law and the Use of Force (I993), I79.

5. Claude, supra note I, at 84 . See, e.g., D. D. Caron, 'The Legitimacy of the Collective Authority of the Security Council', (I993) 87 AJIL 552, at 56r; S. D. Murphy, 'The Security Council, Legitimacy, and the Concept of Collective Security after the Cold War', (I994) 32 Columbia Journal of Transnational Law 201, at 209.

6. S. C. Schlesinger, Act of Creation: The Founding of the United Nations (2003), I 93-207.

7. I. Brownlie, Principles of Public International Law (2003), 706. 
members has the potential to undermine the authority of the Council as the unique collective security organ of the most important universal organization, and may affect the rules governing the use of force.

Although always described as operating in a 'political' environment, any antilegal behaviour by the Security Council or the permanent members potentially undermines the authority of the Council but may also affect the legal scheme of the UN Charter. It will be seen that this danger is most apparent when the Council is operating within the wider context of threats of force, as occurred in the build-up to war in Iraq early in 2003. Whether this behaviour undermines what Brownlie has called the 'international consensus', namely that 'individual States, or a group of States, cannot resort to force (for purposes other than self-defence) except with the express authorization of the United Nations, ${ }^{8}$ will be discussed in this article. That both the rules of the Charter on the use of force and the authority of the Council must be reappraised after the Iraq crisis of 2003 is demonstrated by the statement made by Hans Blix, former executive chair of the UN Monitoring, Verification and Inspection Commission (UNMOVIC), in February 2004:

The states which we would have expected to support and strengthen some basic principles of the UN order, in my view, set a precedent of ignoring or undermining this order by acting too impatiently and without the support of the Security Council. As a result, their own credibility has suffered and the authority of the UN Security Council has been damaged. ${ }^{9}$

In tracing the will of the Security Council through to its expression in resolutions and then to its interpretation, implementation, and, on occasions, prevention by the permanent members, focus will be given to the calamitous events leading to the invasion and occupation of Iraq by the United States and the United Kingdom in 2003. The first issue, however, is to establish what is meant by 'separate will' and whether the Security Council has such.

\section{The WILl OF THE SECURITY COUNCIL}

The issue of the will of the Council has to be approached by answering the more general question about the presence of separate will in inter-governmental organizations. What signifies that an international organization is an autonomous actor on the international plane? Historically the debate has been about the existence of separate will or volonté distincte, and traditionally the conundrum has been, 'How . . can an international organization, "made" by states which have no superiors in international law, be independent of the will of its members?'10

Schermers and Blokker suggest that an organization must have at least one organ with a will of its own. ${ }^{\text {II }}$ Will is often expressed by international lawyers as

8. Ibid., 7 I 4. See also I. Brownlie, International Law and the Use of Force by States (I963), vii.

9. From a speech given at the University of Edinburgh, Independent, 25 Feb. 2004, 29.

Io. D. J. Bederman, 'The Souls of International Organizations: Legal Personality and the Lighthouse at Cape Spartel', (I 996) 36 Virginia Journal of International Law 275, at 357.

I I. H. Schermers and N. M. Blokker, International Institutional Law (2003), 34. 
the possession of international legal personality, although it can more widely be expressed as the transference of will by the founding states to an organization or the restrictions on the will of member states by an organization. ${ }^{\mathrm{I} 2}$ The concepts of international legal personality and that of separate will are conflated to a large extent. Although the former is a much more legalistic concept than the latter, for international law the existence of separate will is largely encapsulated by the concept of international legal personality. An organization with certain elements is presumed to have international legal personality. ${ }^{\mathrm{I} 3}$ Those elements vary between writers, with some emphasizing permanency, separate purposes, and distinct powers, as well as organ(s); ${ }^{\mathrm{I} 4}$ while others include organ(s), membership, and decision-making. ${ }^{\mathrm{I5}}$ While the existence of separate will is embodied in the concept of international legal personality, the extent of separate will is to be found in the nature of those elements: for instance in the presence of majority voting in the organs, the width of purposes, the intrusiveness of powers, the nature of decision-making, and the depth of membership. These reflect the fundamental legal nature of the organization, which may tend towards the contractual or the constitutional. ${ }^{\text {I6 }}$

Organizations without personality - the $\mathrm{G} 7$ for instance - can be said to have a separate existence but not a separate will, at least in a legal sense. True, the G7's communiqués reflect the collective view of seven states but, without separate will, such communiqués do not have legal status as $\mathrm{G} 7$ decisions per se. Without separate will the $G_{7}$ certainly has no lawmaking power. Regular $G_{7}$ meetings indicate its separate existence, but states have not transferred any of their will to the $G_{7}$, or given the G7 the elements that would enable it to develop a will of its own. Thus 'for an international entity to be regarded as existing separately from its Member States, the entity must have a decision-making organ that is able to produce a "corporate" will, as opposed to a mere "aggregate" of the wills of the Member States'. ${ }^{17}$ Nevertheless, the impact of certain fora lacking formal personality should not be underestimated. As Blokker notes, "G8 consensus was crucial in the spring of I999 to "solve" the Kosovo crisis'. ${ }^{\text {8 }}$

A decision of the Security Council adopted in accordance with its voting rules ${ }^{19}$ is a reflection of the corporate will of the Security Council, not the aggregation of the wills of the members of that body. The separate personality of the United Nations

I 2. States are often resistant to the latter view. See the criticism by the UK minister on the draft EU Constitution: 'It is not the constitution that grants competences, but the member states, through the constitution'. R. Watson, 'Giscard's Plan for Europe Swamped by Amendments', The Times, 25 Feb. 2003 , I6.

I3. C. F. Amerasinghe, Principles of the Institutional Law of International Organizations (I996), 89-90; J. Klabbers, 'Presumptive Personality: The European Union in International Law', in M. Koskenniemi (ed.), International Legal Aspects of the European Union (I998), 243-9.

I4. Brownlie, supra note 7, at 649. See further Amerasinghe, supra note I3, at 83; R. Higgins, Problems and Process: International Law and How We Use It (I994), 47.

I5. R. A. Wessel, 'Revisiting the International Legal Status of the EU', (2000) 5 European Foreign Affairs Review 507 , at 517 .

I6. For discussion of capacities and competences see P. H. F. Bekker, The Legal Position of Intergovernmental Organizations (I994), 5I-85.

I7. Wessel, supra note I5, 5I7.

I8. N. M. Blokker, 'Proliferation of International Organizations: An Exploratory Introduction', in N. M. Blokker and H. G. Schermers (eds.), Proliferation of International Organizations: Legal Issues (200I), I, at 6.

I9. UN Charter, Art. 27. 
establishes the will of the organization as a whole, although in the case of the Security Council there is a concentration of will, enabling it, for example, to take mandatory decisions imposing non-military measures binding on the whole membership, a power it has utilized significantly with the end of the Cold War. The International Court of Justice in the Reparation case was inaccurate in stating that the United Nations had a large measure of personality; ${ }^{20}$ personality is, after all, either present or not. The Court was possibly alluding to the fact that the Charter confers a large measure of separate independent will on the United Nations, more on certain organs than on others. Personality is the starting point for legal analysis; after that the extent of each organ's will is to be found in their capacities or competences. Legal powers are a significant element in any analysis of this nature and these may be conferred expressly or impliedly by member states, or may be developed and deployed by the organization itself. The competence to legislate to create international criminal tribunals or to legislate to combat terrorism, ${ }^{21}$ for instance, can hardly be said to have been the intention of the founding states; in reality they are a creation of the Security Council itself, a product of its separate will.

That the Council potentially had significant separate will was evident in 1945 . Indeed, what occurred was a collective action of states imbuing the Security Council with unique powers that individual states did not possess thereafter. Even if states had a collective police power before I945, at that point they embodied it for better or for worse (though the intention was to improve the ambiguous and selective nature of collective interventions) in the Security Council. ${ }^{22}$ It would be accurate to state that the parameters, even the existence, of such a collective power before the advent of the UN Charter was legally highly doubtful. It was by establishing the United Nations that the majority of states decided to establish a body with novel competence. The adoption of the UN Charter in 1945 was a defining moment, not in the sense of codifying an already existing legal regime, although one was arguably emerging during the course of the Second World War with the idea of the United Nations, ${ }^{23}$ but in the sense of creating a new world order, with the Charter having the role of foundational constitutional document. Thereafter the United Nations possessed powers which states did not, and arguably never did, possess. The decision to impose economic sanctions or authorize military action to deal with threats to the peace as well as with acts of aggression belongs to the Security Council, although subsidiary responsibility arguably falls to the General Assembly. ${ }^{24}$ Even a modernday advocate of anticipatory self-defence accepts that while the Security Council can take action against threats that are not imminent, states cannot. ${ }^{25}$

\footnotetext{
20. Reparation for Injuries Suffered in the Service of the United Nations, Advisory Opinion, [I949] ICJ Rep. I74, at I79.

2I. SC Res. I373, 28 Sept. 2001.

22. Brownlie, supra note 8,332-3; D. Sarooshi, The United Nations and the Development of Collective Security (I999), 26-32.

23. See 'Declaration by the United Nations', I Jan. I942, in R. B. Russell and J. M. Muther, A History of the United Nations Charter (1958), Appendix C.

24. See N. D. White, 'The Legality of Bombing in the Name of Humanity', (2000) 5 Journal of Conflict and Security Law 27.

25. C. Greenwood, 'International Law and the Pre-emptive Use of Force: Afghanistan, Al-Qaida, and Iraq', (2003) 4 San Diego International Law Journal 7, at 36.
} 


\section{The AUTHORITY OF THE SECURITY COUNCIL}

Once the Cold War ended and the Security Council did start taking copious amounts of action in developing its corporate will, there emerged other dangers to the UN Charter scheme. Of course concerns about such dangers must be balanced against the benefits to world peace that an active Council brings. Powerful states realized the potential of the Security Council given the huge range of its powers and the limited forms of accountability for their exercise. In general terms of legality and legitimacy Security Council approval is the golden fleece that powerful states seek to justify not only coercive non-defensive action, but also other actions that infringe a state's sovereignty. This is graphically illustrated by the tremendous diplomatic efforts put into securing 'post-conflict' Council resolutions on Iraq in 2003-4, endorsing first of all the occupation of the country by the United States and the United Kingdom, then the creation of a multinational force, and finally the formation of a sovereign interim government of Iraq. ${ }^{26}$

All those serious remaining doubts after Kosovo as to whether a state can undertake humanitarian intervention or anticipatory action are swept away if the Security Council authorizes it as a response to a threat to the peace. Whatever the weaknesses of the Council, recent conflicts in Kosovo and Iraq, even Afghanistan, showed the unique authority of that organ in collective security matters, as the states using force attempted to justify their actions as coming under Security Council resolutions. If powerful states manage to persuade the Council to adopt resolutions tackling threats to or breaches of the peace within the meaning and purposes of the Charter as developed by practice, then the international community generally accepts the legitimacy of such actions and will support the Council. Witness the support for the Coalition in the Gulf conflict of I 991. ${ }^{27}$

This support, however, is subject to the Council acting within its competence. Although the original UN member states at San Francisco recognized that each organ determined its own competence, ${ }^{28}$ the ability of the Council to induce the compliance of the whole membership will be reduced if it is generally perceived as acting beyond the framework of the Charter. ${ }^{29}$ Although mechanisms of political accountability in the United Nations are not strong, there is a rudimentary form of accountability to member states: remember that most Council decisions, particularly those adopted under Article 4I, depend on states to act on them, for instance by not trading with a sanctioned state. A resolution may be binding under Article 25 of the Charter, but the actual implementation and therefore effectiveness of the action will ultimately depend on states themselves taking the necessary actions against their citizens and companies. ${ }^{30}$ Council authority is thus diminished by actions that have the quality of ultra vires decisions, and importantly are perceived as such by the wider membership.

26. SC Res. I483, 22 May 2003; SC Res. I5I I, I6 Oct. 2003; SC Res. I546, 8 June 2004.

27. P.-M. Dupuy, 'The Constitutional Dimension of the Charter of the United Nations Revisited', (I997) I Max Planck Yearbook of UN Law 20.

28. UNCIO, vol. I3, 709 .

29. T. M. Franck, Fairness in International Law and Institutions (I995), 26.

30. Murphy, supra note 5, at 209. 
Of course it is possible that a lawful decision of the Security Council can still be viewed as illegitimate by the membership judging against 'some broader frame of reference'. ${ }^{\text {I }}$ But this appears to be relatively rare in UN practice. Often the picture is much more blurred, with resolutions against Libya and against terrorism having question marks raised against their legality rather than there being a black-andwhite consensus about their legality. Such question marks affect the legitimacy of the Council's decisions and thus undermine its authority, but not as greatly as a clear ultra vires resolution.

It is not proposed here to detail legally problematic measures taken by the Council. Such discussions have dominated legal literature on the Security Council in the past decade. ${ }^{32}$ There has been a continuing debate since the measures taken against Libya in $1992^{33}$ about the limitations on the competence of the Security Council. Libya raised concerns regarding the use or misuse of the concept of threat to the peace by the Council, as well as the ability of the Council to override existing treaty rights and duties of states by virtue of Article ro3 of the Charter (in that case the treaty rights of Libya arising under the Montreal Convention of I97 I to prosecute two suspects). ${ }^{34}$ The issue was intensified with the adoption on I2 July 2002 of Resolution I422, which grants immunity from the International Criminal Court (ICC) to personnel from non-states parties involved in UN-established or -authorized missions for a renewable twelve-month period; here there was no explicit finding of a threat to the peace in what purported to be a Chapter VII resolution, and the Council was not simply overriding the obligations of member states under the ICC Statute but the obligations of the Court itself. 35

Furthermore, there is no specific Charter provision in Chapter VII that can expressly or implicitly be used to justify the decision made in Resolution I422. Article 4I has been used as the peg on which to hang new developments by the Security Council: for example international criminal tribunals for the former Yugoslavia and Rwanda, ${ }^{36}$ and modern-day protectorates in Kosovo and East Timor. ${ }^{37}$ Both of these innovations can be seen as encouraging legitimate developments of the Security Council's concern to promote a positive peace, a peace where protection of human rights is combined with security. Thus they are prima facie compatible with the purposes of the United Nations as developed in practice since I945. However, it is stretching Article 4I beyond breaking point to see the immunity of certain personnel serving in UN forces as a 'measure not involving the use of armed force'. It is certainly not a 'measure' in the sense of economic or diplomatic sanctions,

\footnotetext{
3I. Caron, supra note 5, at 559.

32. See, e.g., J. E. Alvarez, 'Judging the Security Council', (I996) 90 AJIL I.

33. SC Res. 748, 3I March I992.

34. See discussion of the inconclusive Lockerbie cases in N. D. White, 'To Review or Not To Review: The Lockerbie Cases before the World Court',(I 999) I 2 LJIL 4O I. Questions of Interpretation and Application of the I 97 I Montreal Convention Arising from the Aerial Incident at Lockerbie (Libyan Arab Jamahirya v. United Kingdom), Provisional Measures, [I 992] ICJ Rep. 3; Preliminary Objections, [I 998] ICJ Rep. 26.

35. R. Cryer and N. D. White, 'The Security Council and the International Criminal Court: Who's Feeling Threatened?', (2002) 8 International Peacekeeping: The Yearbook of International Peace Operations I43.

36. Tadić case, No. IT-94-I-AR72, paras. 35-36.

37. M. J. Matheson, 'United Nations Governance in Postconflict Societies', (200I) 95 AJIL 76.
} 
or even international criminal tribunals or fourth-generation-style peace-support operations.

The Security Council is a political body. It is inevitable that a member or group of members of such a body wanting it to act in a certain way must persuade the remaining members to its way of thinking. In contrast to the failed proposed second resolution against Iraq in early 2003, the United States won the argument in the case of Resolution 1422 in 2002. Should this mean the end of the matter, since in the words of the ICJ in the Namibia case 'a resolution of a properly constituted organ of the United Nations which is passed in accordance with that organ's rules of procedure, and is declared by the President to have been so passed, must be presumed to have been validly adopted'? ${ }^{38}$ However, sole reliance on that presumption without any accompanying attempt to address the underlying legal problems with the resolution undermines the authority of the Council. The Council is a political body with wide discretionary powers, but that discretion is granted to it by a legal document - the UN Charter. Discretion should and can be exercised in accordance with the law. As early as I948 the ICJ stated in the Admissions opinion that the "political character of an organ cannot release it from the observance of the treaty provisions established by the Charter when they constitute limitations on its powers or criteria for its judgment'.39

The pressure to obtain UN authority for acts that individual states do not have the right to take unilaterally has led to the Council pushing against the constraints of the UN Charter but rarely clearly exceeding its generous parameters. Resolution I 422 is the clearest example of a decision that is extremely difficult if not impossible to reconcile with UN law. However, legally precarious decisions such as those against Libya and those against terrorism in general ${ }^{40}$ may also erode the authority of the Security Council if states view them as tainted and illegitimate and, more particularly, if they do not observe them. ${ }^{4 \mathrm{I}}$ Empirical evidence on the implementation of the Council's anti-terrorism legislation has yet to be gathered, although initial data from the Council's Counter-Terrorism Committee is encouraging in terms of member-state compliance. ${ }^{42}$ Certainly sanctions against Libya did see evidence of non-observance, especially by African states. ${ }^{43}$ Although many states voiced their objections to the drafts that eventually led to Resolution $1422,{ }^{44}$ it is unlikely that there will be any significant testing of states' willingness to comply with it, given the slim possibility of the immunity purportedly given by that resolution being tested..$^{45}$

38. Legal Consequences for States of the Continued Presence of South Africa in Namibia Notwithstanding Security Council Resolution 276 (1970), Advisory Opinion, [I97 I] ICJ Rep. I6, at para. 20.

39. Conditions of Admission of a State to Membership of the United Nations, Advisory Opinion, [I948] ICJ Rep. 57, at 64 .

40. SC Res. I373, 28 Sept. 200 I.

4I. What has been described as the erosion of 'the receptivity of members to the views of the Council' - S. R. Ratner, 'The Security Council and International Law', in D. M. Malone (ed.), The UN Security Council (2004), 59I, at 603.

42. C. A. Ward, 'Building Capacity to Combat International Terrorism: The Role of the United Nations Security Council', (2003) 8 Journal of Conflict and Security Law 289, at 299.

43. E. de Wet, The Chapter VII Powers of the United Nations Security Council (2004), 382.

44. SC 4568th mtg, ro July 2002.

45. Cryer and White, supra note 35, at I59-60. 
Nevertheless, the consequence of such decisions is the potential diminution of the authority of the Council.

The Council, even with the limitation of the veto, has taken measures that may be questionable in terms of the Charter and undermine the development of peace and security based on respect for human rights. On the other hand its development of international criminal tribunals and fourth-generation-type peace-support operations illustrates how the Council can develop its powers to promote a positive peace. The dominant desire in the international community for the United Nations to play the leading role in post-conflict Iraq from April 2003 onwards reflects the unique authority and legitimacy of the United Nations in this role, developed by its practice in Kosovo and East Timor. The Security Council's endorsement of a post-conflict coalition of the willing in Iraq in Resolution $1483^{46}$ is a positive development, in the sense that it at least shows a recognition of the legitimacy that such authority confers by those states previously questioning the relevance of the Council. It is a less appealing development given that the role of the United Nations in the post-conflict stage is much reduced, although Afghanistan in 200I also manifested a downplaying of the United Nations' role in post-conflict administration.

\section{THE EXPRESSION OF WILL}

Resolution 1483 does, however, make it clear that the United States and the United Kingdom must act consistently with the Charter and other principles of international law in post-conflict Iraq, although its terms seem to be deliberately ambiguous. Resolution I483 was adopted under Chapter VII in response to the continuing threat to international peace and security caused by the situation in Iraq. It recognized the 'specific authorities, responsibilities, and obligations under applicable international laws' of the United States and the United Kingdom as 'occupying powers under unified command' called 'the Authority'. ${ }^{47}$ It further called upon 'the Authority, consistent with the Charter of the United Nations and other relevant international law, to promote the welfare of the Iraqi people through the effective administration of the territory, including in particular working towards the restoration of conditions of security and stability and the creation of conditions in which the Iraqi people can freely determine their own political future'.

That resolution and subsequent resolutions on the subject indicate that the process by which the Iraqi people realize their internal right of self-determination is by free and fair elections. True, neither Resolution I483 nor the meeting at which the Council gave authority to the United States and the United Kingdom used the term 'elected' government as the end-product of the realization of internal self-determination, preferring instead the more elliptical phrase, an 'internationally recognized, representative government' of Iraq. ${ }^{48}$ However, the United Nations'

\footnotetext{
46. SC Res. I483, 22 May 2003.

47. On the effect of Resolution I483 on the law of occupation see D. Scheffer, 'Beyond Occupation Law', (2003) 97 AJIL 842.

48. SCRes. I483, 22 May 2003. See SC 476 Ist mtg, 22 May 2003. Only Germany spoke of a 'democratic' government.
} 
consistent promotion of democracy since the early I990s in those member states requesting its assistance has been based on the expression of the will of the people in free and fair elections. ${ }^{49}$ Given this practice, it would have been difficult for the United States and the United Kingdom to deny it as the process for achieving a representative government. As Johnstone rightly observes, 'a given text is always encountered in a situation or field of practice and therefore can only be understood in the light of the position it occupies in that enterprise'. ${ }^{\circ}$ Bearing in mind the specific field of the promotion of democracy by the United Nations, which is based on free and fair elections, it follows that 'representative government' within the context of Iraq means an elected government. ${ }^{\text {I }}$ This was made clear in a later Security Council resolution..$^{2}$ The January 2004 plan of the United States and the United Kingdom to have a selection process for an interim Iraqi government to take over from the Governing Council established in July 2003 at first seems incompatible with the will of the Security Council, although the plan still foresees the holding of elections in 2005 when security within the country has been achieved. 53 This process was not much changed by the adoption of Council Resolution I546 of 8 June 2004, which endorsed the formation of a sovereign interim government of Iraq to take power at the end of June 2004, thereby formally ending the occupation of the country by the United States and the United Kingdom. Although the presence of the multinational force continues after 30 June, the Council recognized the government's ultimate authority over outside military forces that is inherent in sovereignty by declaring that if requested by the government of Iraq the Council will terminate the I 2-month mandate of the US-led force.

The ongoing debate on how to realize the obligations imposed on the United States and the United Kingdom by the grant of authority from the Council is just the latest example of the interpretation of Council resolutions. In the case of Iraq this has been a continuing issue, with the vast panoply of resolutions on Iraq being subject to varying interpretations, none more so than Resolution I44I adopted on 8 November 2002 as the impetus towards war was rapidly gaining momentum.

\section{I. Interpreting Resolution I44I}

Powerful states do not always get what they want from the Council. In such a situation there has been a trend towards such states interpreting Council decisions in ways that breach the understanding underlying the resolution. In these cases other member states, while not necessarily accepting the interpretations given to the decision, will view the Council warily since it appears that action is being taken in its name. This must again affect the authority of the Council. If it appears

49. N. D. White, 'The United Nations and Democracy Assistance: Developing Practice within a Constitutional Framework', in P. Burnell (ed.), Democracy Assistance: International Co-operation for Democratization (2000), 67.

50. I. Johnstone, 'Security Council Deliberations: The Power of Better Argument', (2003) I4 EJIL 437, at 444.

51. See further A. Orakhelashvili, 'The Post War Settlement in Iraq: The UN Security Council Resolution I483 (2003) and General International Law', (2003) 8 Journal of Conflict and Security Law 307, at 3 I 2-I 3 for the view that the peremptory norm of self-determination also requires that the resolution be interpreted in this way.

52. SC Res. I5I I, I6 Oct. 2003. See also SC 4844th mtg, I6 Oct. 2003.

53. R. McCarthy, 'US Must Quit Iraq before Vote, Say Sunnis', Guardian Weekly, 29 Jan.-4 Feb. 2004. An interim Iraqi constitution was agreed by the Iraqi Governing Council on 8 March 2004. 
that resolutions can be pulled this way and that, or can be resurrected after a number of years, or can be enforced even though there is no provision in them for coercion, then member states will rightly view resolutions with a great deal of scepticism. The continuation of such a trend, combined with the Council's endemic selectivity, means that member states will no longer respect the authority of the Council. Its unique position in the international system as the primary body for collective security will be undermined. The point is that it is not the effectiveness or ineffectiveness of the Security Council that calls into question the Charter scheme, but the authority the Council has when it takes action, and the effect on its authority when action is taken under its name. If it takes action that the majority do not accept as clearly intra vires, then its authority is diminished; and if action is being taken under its name that the majority does not accept as legitimate then its authority is being abused and diminished. The latter in particular threatens the Charter scheme for collective security, for it has led to states threatening or using force in the name of the United Nations, thus potentially eroding the prohibition on the threat and the use of force under Article 2(4).

In many ways the Iraq crisis of 2003 was the culmination of a decade of pressure by the United States and the United Kingdom directed at changing the legal framework governing the use of force contained in the UN Charter, in a concerted effort to widen both exceptions to the ban on the threat or use of force in Article 2(4) - namely the right of self-defence contained in Article $5 \mathrm{I}$ - and military action taken under the authority of the Security Council derived from Article 42. After the adoption of Resolution I44I on 8 November 2002, the United States and the United Kingdom brought the above-mentioned pressures to bear by making the claim that the resolution was sufficient to justify the use of force against Iraq even though it did not contain clear authorizing language. Furthermore, the United States claimed that even if the resolution did not authorize force, and in the absence of a further, clearer resolution, it still had the right to use force in self-defence against the threat posed against it by Iraq. According to these views the use of force against Iraq was justified under either or both exceptions to the ban on the use of force, despite the fact that I44I did not authorize measures necessary against Iraq (the accepted mode of delegation under Article 42) and the fact there had been no armed attack against the United States by Iraq within the meaning of Article 5 I.

The focus here will not be the pressure that has been exerted on Article $5 \mathrm{I}$ by wars waged against Afghanistan ${ }^{54}$ and Iraq. Afghanistan must be understood in the context of the emotions provoked by the horrific and profoundly symbolic destruction of the twin towers, while in Iraq, although much has been made of the Bush doctrine of pre-emptive defence, in the end the United States came back to arguments about the interpretation and enforcement of Security Council resolutions demanding the disarmament of Iraq. ${ }^{55}$ When considering the military actions in Iraq (2003),

\footnotetext{
54. See J. I. Charney, 'The Use of Force Against Terrorism and International Law', (200I) 95 AJIL 835, at 835, questioning the claim of self-defence against Afghanistan. But see T. M. Franck, 'Terrorism and the Right of Self-Defense', (200I) 95 AJIL 839, at 840.

55. UN Doc. S/2003/35I, 2 I March 2003.
} 
Afghanistan (200I), and earlier in Kosovo (I999), there does seem to be significant practice by powerful states that lends credence to the idea that force can be used in support of Security Council resolutions, especially (and probably only) those that have made a crucial finding of a threat to or breach of the peace under Article 39 of the UN Charter, although they do not contain an express 'authorization' to take 'necessary measures'. It is interesting that, in the three main conflicts mentioned, reliance on this ground was strongest in two (Kosovo and Iraq), suggesting a preference for a use of force that can be justified under the UN collective security umbrella rather than customary rights that are exercised unilaterally. Indeed, in Afghanistan much is made of the fact that the Security Council apparently endorsed the exercise of the right of self-defence. ${ }^{56}$ The greater legitimacy that UN authority brings ${ }^{57}$ has created tremendous pressures within the Security Council and on its resolutions.

The desire to bring actions under the authority of the United Nations reflects an acceptance of this as a mechanism for lawfully using force, but it also inevitably results in spurious claims by some states to be acting under UN authority. It is also telling that, despite the invocation of the Bush doctrine in September $2002,{ }^{58}$ the United States was persuaded at least temporarily not to invade Iraq on the basis of a claim to pre-emptive self-defence but on the basis of a Security Council resolution. The negotiation of Resolution I44 I took many weeks, and even then the result was not a clear authorization to use force.

Despite the lack of clear authority in Resolution I44I, the United Kingdom in particular subsequently interpreted it to justify the use of force against that country. Interpretations of Security Council resolutions based on a purposive approach ${ }^{59}$ or, more accurately, the principle of effectiveness ${ }^{60}$ may be acceptable if the interpretation reflects the views of the Security Council as a body. The interpretive task is to ascertain what the text means to the parties collectively rather than to each individually' ${ }^{6}{ }^{1}$ Subsequent practice can be relied on to (re)interpret a resolution when it reflects a shared understanding. ${ }^{62}$ Such practice has to be checked against the limitations contained in the Charter and must be undertaken in fulfilment of the purposes of the United Nations. ${ }^{63}$ Subject to these limitations, if the Council members agree that a resolution's wording amounts to an authority to use force then that is what it means. If they disagree and some view it as granting such authority

56. SC Res. I368, I2 Sept. 200I; SC Res. I373, 28 Sept. 200I. But see E. P. J. Myjer and N. D. White, 'The Twin Towers Attack: An Unlimited Right to Self-Defence?', (2002) 7 Journal of Conflict and Security Law 5, at 9-I I.

57. C. Gray, 'From Unity to Polarization: International Law and the Use of Force Against Iraq', (2002) I3 EJIL I, at 8 .

58. 'The National Security Strategy of the United States of America', Sept. 2002, available at http://www. whitehouse.gov/nsc/nss.pdf. See also the UK government's assessment of the threat posed by Iraq in 'Iraq's Weapons of Mass Destruction: The Assessment of the British Government', 24 Sept. 2002, available at http://www.fco.gov.uk/Files/kfile/iraqdosier.pdf.

59. M. Byers, 'The Shifting Foundations of International Law: A Decade of Forceful Measures against Iraq', (2002) I3 EJIL 2 I, at 25.

60. A. Aust, Modern Treaty Law and Practice (2000), I85.

6I. See I. Johnstone, 'Treaty Interpretation: The Authority of Interpretative Communities', (I99I) I 2 Michigan Journal of International Law 37 I, at 38I, where he characterizes the interpretative process as 'intersubjective interpretation'.

62. S. Rosenne, Developments in the Law of Treaties (I989), 244.

63. Certain Expenses of the United Nations, Advisory Opinion, [I962] ICJ Rep. I67-8. 
and others as not so doing, this does not signify that it grants authority, at least in attributing meaning to the Security Council as a whole, as a reflection of its will.

Interpreting a resolution of a body like the Security Council requires careful consideration of the text and the discussions that led up to it. ${ }^{64}$ To interpret the words of a resolution in a way that is directly contrary to the consensus (which may be an agreement to disagree) underlying the resolution would undermine the Council as a forum for achieving compromise. Military action undertaken with Security Council authority is only permitted when there is agreement in that body that such action is being authorized. Agreement to the effect that the Council is authorizing the use of force has been achieved in the past by a formula that combines the phrase 'necessary measures' with an 'authorization'. This has clearly been recognized in UN practice as authorizing the use of force in many instances. ${ }^{65}$ However, there is no need to stick to this formula if the members agree, for example, that a threat of 'serious consequences' in the face of a 'material breach' signifies the authorization of necessary measures or the use of force. But clearly there was no such consensus. ${ }^{66}$ As Johnstone correctly observes, 'In any communicative enterprise, the participants tend to operate according to a set of conventions, practices and shared understandings' ${ }^{67}$ The shared understanding of I44I was that it did not amount to an authority to use force against Iraq.

The consensus at the meeting at which the resolution was adopted was that it did not authorize the use of force if Iraq was in material breach. Indeed, the United States and the United Kingdom asserted to the other members in the meeting that no 'automaticity' or 'hidden triggers' were contained in the resolution, ${ }^{68}$ but then outside the meeting repeatedly stated that there was no legal need for another resolution. ${ }^{69}$ This unilateral interpretation was based on the fact that the resolution not only invoked the concept of 'material breach' at several points but also stated that Iraq had failed to take the final opportunity to comply with its disarmament obligations granted in the resolution, and thus must face the 'serious consequences' warned of. This argument built on the previous justifications put forward since I99I by the United States and the United Kingdom that force was used against Iraq to enforce its disarmament obligations (for example in January I993 and December I998).

64. Namibiacase, supranote 38 , at 53. See further M.C. Wood, 'The Interpretation of Security Council Resolutions', (I998) 2 Max Planck Yearbook of UN Law 73, at 74-5, 79, 95.

65. See generally N. M. Blokker, 'Is the Authorization Authorized? Powers and Practice of the UN Security Council to Authorize the Use of Force by "Coalitions of the Able and Willing”, (2000) I I EJIL 54I.

66. Gray, supra note 57 , at 9.

67. Johnstone, supra note 50 , at 456.

68. SC 4644th mtg, 8 Nov. 2002. Other members spoke about the lack of the automatic right to use force in the resolution (Mexico, Russia, Bulgaria, Syria, Cameroon, China), labelled the ‘two-stage approach' by France, and the clear assurances about the lack of basis in the resolution for the use of force (Ireland, Colombia); while Norway referred to the Council's responsibility recognized in the resolution to secure international peace. The sense of the meeting was best summed up by the representative of Ireland when he thanked the sponsors of the resolution (United States and United Kingdom) for their assurances that the purpose of the 'resolution was to achieve disarmament through inspections, and not to establish the basis for the use of force'.

69. Outside the Security Council Blair stated, 'Defy the UN's will and we will disarm you by force. Be in no doubt whatever about that'. Bush stated, 'The outcome of this crisis is already determined. The full disarmament of weapons of mass destruction will occur. The only question for the Iraqi regime is to decide how. His co-operation must be unconditional or he will face severest consequences'. Independent, 9 Nov. 2002, I and 5. 
Indeed, they argued that the adoption of Resolution I44I signified that the Security Council endorsed their position that material breach of the disarmament provisions of Security Council resolutions, from 687 (of 3 April I99I) to I44I, ${ }^{70}$ suspended the operation of the ceasefire Resolution 687 , thus allowing states to use force under the open-ended provisions of Resolution 678 of 29 November I990. However, it is clear from the statements made at the adoption of Resolution I44I that it was not the intention of the Council to endorse that argument, and that any response to a material breach of the resolution would come from the Security Council, not individual member states, in other words that the 'serious consequences' were to be determined by the Council. The fact that the final version of the resolution left out the words of the original US and UK draft authorizing member states 'to use all necessary means to restore international peace and security in the area' is telling. ${ }^{7 \mathrm{I}}$

Further, it is also clear from the meeting at which I 44 I was adopted, as well as from the history of Security Council diplomacy, that a combination of 'material breach' and 'serious consequences' in the resolution is not understood by the Security Council to include the use of armed force, ${ }^{72}$ though that may be the subsequent interpretation put on the phrase by the United States and the United Kingdom. 'Serious consequences' and 'material breach' were put in the resolution by the United States and the United Kingdom to enable them to make these arguments, as was the recollection of previous resolutions including 678 , but the non-acceptance of this position by the rest of the Council signified that the use of force had not been authorized by the Security Council as a reflection of its will. It is true that Resolution I44I came closer to the US and UK position than previous resolutions dealing with the Iraqi breach of Resolution $687,{ }^{73}$ but it did not meet the agreed requirements that for states to take military action under the auspices of Chapter VII there must be a clear and unambiguous mandate in the form of an authorization to use force. ${ }^{74}$ All other arguments - unilateral interpretations and claims to a right of enforcement fall short, for the simple fact is that if the Council wants to authorize the use of force it will do so using clearly accepted language. It has not done so in the case of Iraq since the end of the conflict in I991. ${ }^{75}$

While maintaining the position subsequently adopted outside the Council that force was legally justified against Iraq without a further Council resolution, in January and February 2003 the United Kingdom in particular moved towards the position that a further resolution was politically desirable, although an 'unreasonable veto' would not deter the United Kingdom from using force. ${ }^{76}$ Even then, the resolution

70. See, e.g., prior to the I 998 air strikes - The Times, I9 Feb. I998.

71. See N. Grief, 'The Iraq Hearing', I9 Dec. 2002, www.bbc.co.uk/radio4/today/reports/archive/international/ iraq-hearing. shtml.

72. But see F. L. Kirgis, 'Security Council Resolution I44I on Iraq's Final Opportunity to Comply with Disarmament Obligations', ASIL Insights (Nov. 2002).

73. See, e.g., SC Res. I I54, 2 Mar. I998; I I94, 9 Sept. I998; I 205, 5 Nov. I 998.

74. J. Lobel and M. Ratner, 'Bypassing the Security Council: Ambiguous Authorization to Use Force, Cease-fires and the Iraqi Inspection Regime', (I 999) 93 AJIL I 24.

75. T. M. Franck, 'What Happens Now? The United Nations After Iraq', (2003) 97 AJIL 607, at 6Io-I4.

76. A. Grice, 'Defiant Blair Says UN Has No Veto on War', Independent, I4 Jan. 2003, I. 
being mooted in early February by the United Kingdom still did not envisage a clear authorization to use force, because in the absence of clear evidence of Iraqi armaments this was thought by the United Kingdom to be unachievable, although it did contain a further determination of a 'material breach'. British officials insisted that this would constitute authority to use force. ${ }^{77}$ The contradiction in this argument is manifest, unless the members of the Security Council had indicated that they had changed their minds and that such language did signify authorization to use force. The unconvincing evidence of the existence in Iraq of weapons of mass destruction (WMD), apparent from the critical but not damning reports from the heads of the UN Monitoring, Verification and Inspection Commission (UNMOVIC) and the International Atomic Energy Agency (IAEA) of 27 January, ${ }^{78}$ I4 February, ${ }^{79}$ 28 February, ${ }^{80}$ and 7 March $2003,{ }^{8 \mathrm{I}}$ as well as the limited evidence presented to the Council by the US Secretary of State on 5 February, failed to persuade most members of the Council to change their view that the use of force was not yet justified. On I4 February the US Secretary of State stated that it was not UNMOVIC's job to produce evidence of Iraqi breach, rather it was the responsibility of Iraq to disarm, which it clearly had not done. According to the United States this was a further material breach and a failure by Iraq to take the final opportunity afforded to them in I44I and should have led to the serious consequences called for in that resolution. ${ }^{82}$ The United Kingdom made it clear that it would support US military action even without a further resolution. On I7 February the UK Foreign Secretary stated that 'in terms of mandate Resolution I44I gives us the authority we need, but in terms of political desirability we have always said that we would prefer a second resolution, ${ }^{83}$ Further, on 2I February he stated that 'diplomatic parlance is notoriously ambiguous, but in this case the terminology had one meaning: disarmament by force. ${ }^{84}$

On 24 February the United States and the United Kingdom introduced a draft second resolution into the Council, although they made it clear that it was for discussion and would not be voted on until after further reports from the weapons inspectors. Legally it seemed to add little to I44I. There was no explicit authorization to use necessary measures. After invoking Chapter VII, the initial draft had one

77. D. Usborne, J. Lichfield, P. Waugh, and A. Penketh, 'Tony Blair, A Man with his Hands Full', Independent, 8 Feb. 2003, I.

78. S/PV 4692nd mtg, 27 Jan. 2003. Blix (UNMOVIC) concluded (p. 8) that there were serious gaps in knowledge about Iraq's chemical and bacteriological weapons programmes, and that Iraq was not fully co-operating. He noted that UNMOVIC capability had increased over a short period of time, inferring that more time was needed. El Baradei (IAEA) concluded by saying (p. I2) that 'we have to date found no evidence that Iraq has revived its nuclear weapons programme since the elimination of the programme in I99o', but that a more definite conclusion could be provided in the next few months if the inspection process was allowed to continue.

79. S/PV 4708th mtg, I4 Feb. 2003.

80. UN Doc. S/2003/232. This report by UNMOVIC was critical of Iraq, stating that it should show greater credible evidence of disarmament. On 28 February Iraq started destroying missiles that exceeded the $150 \mathrm{~km}$ permitted range. Blix, UNMOVIC's chair, stated that this was a 'very significant piece of real disarmament' UN News Service, 28 Feb. 2003.

8I. S/PV 47 I4th mtg, 7 March 2003. Blix referred to the destruction of missiles by saying, 'we are not watching the breaking of toothpicks. Lethal weapons are being destroyed'.

82. S/PV 4708th mtg, I4 Feb. 2003, 2 I.

83. S. Castle, 'France Set to Block Second UN Resolution against Iraq', Independent, I 8 Feb. 2003, I.

84. Independent, 22 Feb. 2003, 4. 
operative paragraph, where it 'decides that Iraq has failed to take the final opportunity afforded to it in Resolution I44I'. The preamble recalled I44I's reference to material breach and warning of serious consequences. In effect it found that Iraq had breached that resolution by 'noting that Iraq has submitted a declaration ... containing false statements and omissions and has failed to comply with, and to cooperate fully in the implementation of' Resolution I44I. ${ }^{85}$ In last-ditch attempts to make this draft acceptable and thus to avoid the threatened vetoes of Russia and France as well as other probable negative votes, the United Kingdom amended the draft to provide for a further short deadline, I 7 March, for Iraqi compliance, and finally to list the various actions Iraq had to undertake to demonstrate compliance. ${ }^{86}$ This did not persuade Russia and France, which insisted that the inspection process was working and should therefore be given several months to work through. ${ }^{87}$ Furthermore, they were probably concerned that the second resolution had become of such symbolic significance for world opinion that its adoption would be seen as giving a green light for war, despite the fact that it was not viewed as so doing by the Council as a whole. More importantly for the United States and the United Kingdom, a second resolution would have served domestic purposes, particularly in the United Kingdom, where the public was much more willing to support the use of force if a second resolution could have been adopted.

The failed efforts to obtain a second iconic resolution in the Council meant that when full-scale conflict was engaged in Iraq on 20 March, American rhetoric had moved towards claiming that the legal basis was self-defence by reiterating its reliance on pre-emptive action. When debates were going against the draft on 7 March 2003, President Bush stated that 'we don't really need the United Nations' approval to act... When it comes to our security, we do not need anyone's permission, ${ }^{88}$ Further, on I 8 March he outlined the nature of the threat. 'The danger is clear. Using chemical, biological or, one day, nuclear weapons obtained with the help of Iraq, the terrorists could fulfil their stated ambitions and kill thousands or hundreds of thousands of innocent people in our country or any other'. ${ }^{89}$ However, in its letter to the Council reporting its initiation of hostilities against Iraq, the United States relied on Security Council resolutions. ${ }^{90}$

The United Kingdom preferred to argue solely that the war was legally justified on the basis of existing Security Council resolutions. In a parliamentary written answer on 17 March 2003, the Attorney General stated that the basis for force was Resolution 678 of I990, containing the original authority to use force. The Attorney General argued that this authority was reactivated in the light of material breach of Resolution 687 of I 99 I, which imposed conditions on the defeated Iraq including the disarmament of its chemical, biological, and nuclear capability, and all subsequent

85. http://news.bbc.co.uk/go/pr/fr/-/hi/world/europe/2795747.stm.

86. UN Doc. S/2003/2 I 5, 7 March 2003.

87. See D. Usborne, 'On the Brink of War', Independent, 8 March 2003, I.

88. R. Cornwell, 'The Quiet Man', Independent, 8 March 2003, 3.

89. http://news.bbc.co.uk/I/hi/world/middle_east/2858965.stm.

90. UN Doc. S/2003/35I, 2I March 2003. See further W. H. Taft and T. F. Buchwald, 'Pre-emption, Iraq and International Law', (2003) 97 AJIL 557. 
disarmament resolutions up to and including Resolution I44I. He concluded that 'all that resolution I44I requires is reporting to and discussion by the Security Council of Iraq's failures, but not an express further decision to authorize force', ${ }^{\text {II }}$ since there was original authority in 678 . The weakness of this argument has been demonstrated by the fact that it was not accepted by other members of the Council -it is in effect a misrepresentation of the will of the Council. This by itself is sufficient to dispose of the argument that relies on an interpretation of Security Council resolutions. Besides which the interpretation itself is flawed by reason of the fact that the authority of Resolution 678 does not extend beyond Resolution 687, where the Council declared in the final paragraph that it remained 'seized of the matter' and would 'take such further steps as may be required for the implementation of this resolution and to secure peace and security to the area'. The delegation of power to take military action that occurred in Resolution 678 in November 1990 was effectively revoked by Resolution 687 of April, including the authority in 678 to restore 'international peace and security to the area'.

For the Attorney General to state that 'material breach of resolution 687 revives the authority to use force under resolution 678 ', which is the crucial step in his reasoning back to 678 , has no basis in those resolutions and thus no basis in law. It represents an unconvincing attempt to unlock Resolution 678, which was the only resolution in which the Council authorized necessary measures against Iraq. Resolution 678 authorized member states 'to use all necessary means to uphold and implement resolution 660 (I990) and all subsequent resolutions and to restore international peace and security to the area'. However, the Council meeting at which 678 was adopted showed that members viewed this as giving the Coalition authority to push Iraq out of Kuwait and to restore peace between the two states, not to take any wider action..${ }^{22}$ It thus could not be extended beyond the recapture of Kuwait. The United Kingdom's interpretation of Resolutions 678 (I990), 687 (I99I), and I44I (2002) in effect ignores the will of the Council expressed at the time of their adoption.

It is interesting to see that in the year after the invasion of Iraq, with the occupation by the United States and the United Kingdom continuing, attention has turned in both the United States and the United Kingdom to the issue of whether there was evidence prior to the invasion that Iraq posed a sufficient threat to those countries. ${ }^{93}$ Though the political discourse in these countries seems to be turning essentially to issues of self-defence, it must be remembered that the arguments that the United States and the United Kingdom were enforcing or applying Council resolutions on disarmament in the end rely heavily on there being WMD in Iraq. Technically, however, a 'material breach' of Resolution I44I does not necessarily

9I. http://news.bbc.co.uk/I/hi/uk_politics/2857347.stm (also (2003) 52 ICLQ 8I9). See further C. Greenwood, supra note 25, at 35-6.

92. S/PV 2963rd mtg, 29 Nov. I 990, 78 (UK), IOI (US). The meeting at which SC Res. 687, 3 April I 99 I, was adopted showed that member states viewed the authority to authorize further measures as belonging to the Council, not to those states acting under 678 -S/PV 298I, 3 April I 99I, 85 (US), I I I (UK), 95 (China), 98 (USSR).

93. The main issue in the United Kingdom is the suspect evidence presented to Parliament at various points before the outbreak of hostilities on 20 March 2003 to the effect that Iraq could deploy WMD within an hour of the order being given. A. McSmith, 'The 45-minute Case Collapses', Independent, 8 Feb. 2004, I. 
require there to be such weapons. However, in terms of convincing the public and wider world opinion, the issue of whether Iraq had WMD at the time of the conflict is germane both to the self-defence argument (where their presence can be evaluated in terms of the threat posed by them) and to the enforcement or application of Council resolutions (where their presence would be a clear violation of those resolutions).

The critical reaction of many states and other actors to the decision of the United States and the United Kingdom to use force without Security Council authority is of course significant in evaluating the legality of that action as well as the legitimacy of their interpretations of Security Council resolutions. On ro March, before the outbreak of war, the UN Secretary-General was clearly of the opinion that it would be unlawful when he warned that if the US and others were to go outside the Council and take military action it would not be in conformity with the Charter'. ${ }^{94}$ Criticisms of the impending war and warnings of illegality were voiced by the majority of members of the Council when meeting on the eve of the war. ${ }^{95}$ After full-scale force was unleashed by the United States and United Kingdom on 20 March 2003, there were immediate statements condemning it as a violation of international law by China, Russia, France, Iran, Pakistan, India, Indonesia, and Malaysia, while support was given by Australia, the Philippines, Japan, and South Korea. ${ }^{96}$

The Security Council debates on Iraq and the reactions of states to the unauthorized use of force on 20 March 2003 show that to argue that a new purposive interpretative rule has been accepted that allows individual states unilaterally to interpret and enforce Security Council resolutions and even the UN Charter ${ }^{97}$ does not reflect the consensus of the international community. The fact that the same minority of states that seeks to justify the above interventions argues for the emergence of a new rule of interpretation is sufficient to show that such arguments are self-serving and are not accepted by the vast majority of states. In reality a Security Council resolution is not a treaty text to be pulled this way and that over many years, it is a document of an executive body charged with taking action within its competence to fulfil the purposes of the UN Charter. As a piece of subsequent practice adopted under the auspices of a treaty, each resolution exists primarily as a reflection of the will of the Security Council. ${ }^{8}$ That will can change - for example

94. UN News Service, ro March 2003, available at http://www.un.org/apps/news/printnews.asp?nid=6399.

95. S/PV 472I mtg, I9 March 2003. Statements by Germany, France, Russia, Syria, Pakistan, Mexico, Chile, Angola, China. See also open meeting of Security Council S/PV 47I7, I2 March 2003, when representatives of 5 I states spoke.

96. http://news.bbc.co.uk/I/hi/world/middle_east/2867027.stm. The United States claimed that 30 countries were supporting the military action. "Under the standards used by the current Bush administration, the size of the I99 I coalition is likely to have been more than roo countries' - E. MacAskill, 'US Lists Coalition of the Willing', Guardian Weekly, 27 March-2 April 2003, 5. In fact 34 countries contributed militarily to the I99I campaign, while four countries contributed to the 2003 campaign (United States - 200,000 personnel; United Kingdom - 45,000; Australia - 200; Poland - 200). In I99I the US-led coalition acted under a UN resolution and had broad support not only in the Security Council but also in the General Assembly - see GA Res. 46/I35, I7 Dec. I99i.

97. Byers, supra note 59 , at 27.

98. Wood, supra note 64, at 77, 95. See also H. Thirlway, 'The Law and Procedure of the International Court of Justice' (I996) 67 BYBIL 29. But see C. Stahn, 'Enforcement of the Collective Will After Iraq', (2003) 97 AJIL 804 , at 822 , for the view that the Iraq crisis was a challenge to 'the old dogma that the Council alone is entitled 
the Council could decide that Resolution 242 (I967) on the Middle East is clearly binding on Israel - but that would require a further resolution or statement by the Council as a whole.

\section{Security Council authority and threats of ForCe}

However encouraging the critical reaction of states and other actors to the invasion of Iraq, this should not automatically be taken at face value as a reassertion of the fundamental norm contained in Article 2(4) of the Charter; in particular, it must not be forgotten that that prohibition covers the threat as well as the use of force. The question as to whether the Council and the wider membership had half-compromised Article 2(4) by not condemning the threats of force made by the United States and the United Kingdom against Iraq in the build-up to war needs consideration. It may appear that states (and the Council) were more willing to tolerate threats of force than the use of force. Indeed, it may seem justifiable to tolerate threats of force as opposed to the use of force, ${ }^{99}$ but this ignores the fact that threat and use are not so easily separated. Inevitably, if threats are to be credible they must be carried through in the face of intransigence. Threats are not somehow stand-alone devices. To make the threats of force against Iraq credible there was a huge build-up of forces in the Gulf, creating a momentum towards war that was difficult to stop. Indeed, the slide from threat of war to war itself is seen in the escalation of air strikes against Iraq early in March 2003 by the United States and United Kingdom, even though diplomatically the decision to cross the threshold from threat to use of force was not made until 20 March. ${ }^{\text {.0o }}$

The fact that states do not appear willing to condemn threats should not readily be interpreted as acceptance of their legality, for if states do not accept the use of force they are also rejecting the threat of that use of force. ${ }^{\text {IOI }}$ Furthermore, one should not quickly assume acceptance in the face of rules that are peremptory, such as that prohibiting the threat or use of force in Article 2(4). When practice is apparently violative of a peremptory norm, it is not enough to have acquiescence in the face of the violation in order to establish a new or extended right. It is argued that there needs to be more positive acceptance of the claim, positive proof that states have accepted the modification of the peremptory norm, proof in other words of opinio juris. Arguments about acquiescence seem to assume the emergence of new rights in a legal vacuum, but that is not the case. Brownlie puts this clearly when he states that 'the major distinguishing feature of such [peremptory] rules is their relative indelibility. They are rules of customary law which cannot be set aside by treaty or acquiescence but only by the formation of a subsequent customary rule to contrary effect'. ${ }^{\text {102 }}$

to interpret and enforce its will'.

99. R. Sadurska, 'Threats of Force', (I988) 65 AJIL 239.

I00. R. Cornwell, 'US Hits Roadblock in Push to War', Independent, 4 March 2003, I.

IOI. N. D. White and R. Cryer, 'Unilateral Enforcement of Resolution 687: A Threat too Far?', (I999) 29 California Western International Law Journal 243, at 244-55.

I02. Brownlie, supra note 7 , at 488 . 
Even if acquiescence in the face of behaviour that is contrary to a peremptory norm were sufficient, care must be taken in analyzing the quality of any acceptance that may be implied. Why would less developed and weak states accept the dismantling of the collective security structure that at least provides them with rules that purport to protect their vulnerability? In seeking an answer account must be taken of the pressure being exerted on them not to criticize military action, and certainly not the threat of military action, being taken against terrorist organizations or rogue states by powerful states. President Bush sounded a warning against such criticism on 6 November 200I, when he stated that those nations not 'for' the United States were 'against us'. ${ }^{\text {I03 }}$ While acquiescence can be viewed as acceptance, one must be careful not to assume this. As Brownlie states, 'the real problem is to determine the value of abstention from protest by a substantial number of states in face of a practice followed by some others. Silence may denote either tacit agreement or a simple lack of interest in the issue'. ${ }^{\mathrm{IO}}$ Clearly the latter does not constitute acceptance, and if this is the case acceptance cannot be presumed when the silence is a result of fear of the potential political and economic consequences of protest.

To overcome objections based on the peremptory nature of the customary rule prohibiting the threat or use of force, arguments must be made that only parts of Article 2(4) are jus cogens ${ }^{105}$ or that the rule as a whole is dead through constant breach. ${ }^{\text {I06 }}$ Admittedly, in the face of regular breach even of fundamental rules, states in the General Assembly and other fora must affirm allegiance to the rule, for even peremptory norms may eventually be eroded. There is a pressing need for a declaratory General Assembly resolution reaffirming the rules on the use of force in the post-Cold War era. While there has been no recent resolution along the lines of the 1970 Declaration on Friendly Relations ${ }^{\text {I07 }}$ or the 1987 Declaration on the Non Use of Force, ${ }^{108}$ for instance, there have been references to the prohibition of the threat and use of force in resolutions supported by the majority of states since II September, ${ }^{\text {Iog }}$ as well as some encouraging statements by the ICJ in the Oil Platforms case. ${ }^{\text {IIO }}$

Furthermore, the Security Council, in its handling of the Iraq crisis in 2002-3 against the background of the threat of force by the United States and the United Kingdom, did not endorse the threat of force. There is evidence that the threat of

I03. BBC News, 'Bush Urges Anti-Terror Allies to Act', 6 Nov. 200I, http://news.bbc.co.uk/hi/english/world/ americas/newsid_I642000/I642130.stm.

I04. Brownlie, supra note 7 , at 7-8.

I05. R. Müllerson, 'Plus Ça Change (le Monde) Plus C'est la Même Chose (le Droit)?' (2002) 7 Journal of Conflict and Security Law I 49 , at I 69.

Io6. T. M. Franck, 'Who Killed Article 2(4) or: Changing Norms Governing the Use of Force by States' (I970) 64 AJIL 809.

107. GA Res. 2625, 24 Oct. I970.

I08. GA Res. 42/22, I8 Nov. I987.

I09. GA Res. 56/I5I, I 9 Dec. 200I, on the promotion of a democratic and equitable international order, adopted by a vote of Iog to 53 with 6 abstentions; GA Res.56/I52, I9 Dec. 200I, on respect for the purposes and principles contained in the Charter of the United Nations to achieve international co-operation in promoting and encouraging respect for human rights and for fundamental freedoms and in solving international problems of a humanitarian character, adopted by a vote of Ioo to 54 with I 5 abstentions.

I I. Case Concerning Oil Platforms (Islamic Republic of Iran v. United States of America), Merits, [2003] ICJ Rep. paras. 46-78. See further the Separate Opinion of Judge Simma. 
force that formed the background to the inspection process after the adoption of Resolution I44I in November 2002 was not ignored by Security Council members, but no clear position was taken on it by that body. There was no doubt that the threat of force by the United States and the United Kingdom in this period led to Iraq's acceptance of a new inspection process and grudgingly slow co-operation with UNMOVIC and the IAEA. At one level all the Security Council was doing was taking advantage of the threat without endorsing it, and if it had decided to authorize the use of force in a second resolution it would have been accepting the threat only for the purpose of enforcing its will. The failure to authorize the use of force could then been seen as a rejection of the threat that preceded it. However, the evidence is that those states opposing a second resolution authorizing force in February and March 2003 (principally France, Russia, and Germany) would have been content for the inspection process to have continued, a process that was only possible due to a threat of force.

The ambivalent attitude of states and the Council to threats of force, or what has been called 'diplomacy backed by force', apparently endorsed by the SecretaryGeneral in 1998 in relation to Iraq, ${ }^{\text {II I }}$ has a potentially erosive effect on the integrity of Article 2(4). The United Kingdom in particular pointed to this weakness in the position of those states opposed to force when the Foreign Secretary stated on 7 March 2003 that 'the paradox we face is that the only way we are going to achieve disarmament by peace of a rogue regime - which all of us know has been in defiance of this Council for the past I 2 years - the only way we can achieve disarmament of their weapons of mass destruction, which the Council has said poses a threat to international peace and security, is by backing our diplomacy with a credible threat of force'. ${ }^{\text {II2 }}$ While there is clearly a problem with the Council taking advantage of a threat of force by states, it is not possible to say that this amounts to an endorsement of such threats, since states are very well aware that this would potentially remove the barrier to accepting that actual force can be deployed by states to enforce Council resolutions. Nevertheless, by not rejecting the threat of force, there is a danger to the integrity of Article 2(4), although the above analysis shows that it still stands firm.

\section{Authority FOUNDED ON RESPECT FOR LAW}

The premise of this article is that the Council's authority is maintained and strengthened by respect for law, not only by the organ itself in expressing its will but by states purporting to implement that will. The law of the Charter and principles of international law should be respected by the Council when it is considering taking action in new areas. Innovative action by itself is not a bad thing; indeed, it is to be encouraged in an ever-changing security environment, but there are limits to action. There is no doubt that the Council has a very wide competence, allowing it in furtherance of the purposes of the United Nations to respond to threats to and breaches of the peace. However, in rare instances where it adopts resolutions that

II I. White and Cryer, supra note IoI, at 28I.

I I2. SC 47I4 mtg, 7 March 2003. 
only serve the purposes of a permanent member, as with Resolution I422, and not the collective security interest, then it is in danger of exceeding its competence. Of course Council actions can further the national interests of individual states as long as they fulfil the collective purposes of the United Nations. The initial Gulf War of I99I, when US strategic considerations were married to the UN commitment to combat aggression, is a good example.

Authority is being undermined by unilateral interpretations and enforcement of Security Council resolutions. Even though these interpretations are dressed in legal clothes, they are fundamentally anti-legal, given that they contradict the consensus underlying the resolution. They, in effect, disregard the will of the Council. Members of the United Nations engaged in such exercises are undermining the authority of the Council, a process that is exacerbated if the individual states are permanent members of the Security Council. It is argued here that the authority of the Council is dependent not only on that body exercising its will in accordance with law, but also on the individual members themselves, in particular, given its special status, each permanent member. This duty applies not only to the interpretation of Council resolutions but also to the exercise of the veto and to the issue of selectivity, both of which will be briefly considered here and in the conclusion.

\section{6.r. Law and the veto}

Arguments for enhanced Council authority based on law are undermined by the pernicious use of veto. As Brierly pointed out in I946, the veto is a significant flaw in the constitutional edifice of the Charter. ${ }^{I 13}$ For Council action to be taken to uphold those fundamental principles embodied in the Charter there must be agreement among the $\mathrm{P}_{5}$. This represents a realist core in an institutional framework - a political core in a legal regime. Agreement or disagreement among the $\mathrm{P}_{5}$ is the key to Security Council action or inaction, and negotiations between members of this group are shaped by the existence of the veto. Although not often wielded formally in open meetings in the post-Cold War era, the threat of the veto shapes negotiations, as the Iraq crisis of 2003 shows.

What is attempted in this argument is to show that it is possible to constrain the use of the veto by law, while still leaving it intact as a core political power. To recognize greater legal limitations on the veto than those that already notionally exist is to accept the political reality of the continued presence of the veto but also to address the real problem of its abuse which is so undermining to the authority of the Council. Thus while still remaining a special power belonging to a handful of states, the exercise of the veto should only take place within recognized legal parameters. This argument applies to the Council as a whole, which, as a body consisting of I 5 member states, has extraordinary powers; however, as has been shown, these are limited by Charter and international law.

Having said that, British Prime Minister Tony Blair's reference to the 'unreasonable' veto in February and March 2003, ${ }^{\text {II }}$ in relation to the French (and Russian)

I I3. J. L. Brierly, 'The Covenant and the Charter' (I946) 23 BYBIL 83, at 92. 
threats to veto a second resolution that would have more clearly authorized the use of force against Iraq, had no legal basis, at least in the sense used by the Prime Minister. The French veto, although galling to the United Kingdom and to a lesser extent the United States and therefore unreasonable from their perspectives, was being threatened because of a belief that the best way forward was not through the immediate use of force against Iraq but through a lengthier inspection process designed to reveal the extent of Iraq's violations of the Council disarmament resolutions, a belief shared by the majority of the Council, and based on a shared perception of Security Council Resolution I44I. The United Kingdom felt aggrieved that its view of Resolution I44I - that its violation should have led to a second resolution authorizing the use of force or even to an acceptance of the use of force following mere discussions in the Council - was being ignored. However, the fact was that the will of the Council had been clearly expressed at the time of the adoption of I44I, even though the resolution itself was somewhat opaque, to the effect that there were no 'triggers' or 'automaticity' in the resolution establishing a legal basis for the use of force. ${ }^{\text {II5 }}$ This signifies that the French interpretation of the resolution and the process that was to follow from it were not 'unreasonable' even in a political sense, and certainly not in a legal sense. In the case of Iraq, the Council's failure to take further executive action was a product of disagreement between the permanent members. With the veto being validly threatened in order to try to head off precipitous military action, the permanent members should have resorted to further diplomacy to resolve their differences and to achieve a compromise that would have allowed the inspections to continue for a reasonable period. Depending on the outcome of those inspections the Council would then have had to meet to consider what further action, if any, should have been taken against Iraq.

The veto has traditionally been seen as a political expression of power reserved for the Big Five; this was made brutally clear at Yalta even before the San Francisco conference in 1945 . There seemed to be a general acceptance from that point on that it is an exercise of power untrammelled by law, ${ }^{\mathrm{II} 6}$ and that is certainly the way it has been exercised since I945. The veto, however, is contained in a legal document, and is defined in terms that signify that, formally at least, there are legal limitations, albeit limited ones, on its use. Thus there are Charter-based legal limitations on the use of the veto as well as other legal limitations that could also be applicable. The clear legal limitation on the power of veto is that any member of the Security Council, including a permanent member, should abstain from voting if it is a party to a dispute being dealt with by the Council under Chapter VI. ${ }^{\mathrm{II}}$ Due to its wording this limitation appears to have been of limited relevance in practice, ${ }^{\mathrm{II} 8}$ but it is a legal limitation nonetheless.

Legal restrictions on the veto should of course be extended to prevent the veto of Chapter VI resolutions per se. This was argued by the smaller powers at San

II 5. SC 4644th mtg, 8 Nov. 2002.

I 16. B. Simma (ed.), The Charter of the United Nations (2002), 514.

I 17. UN Charter, Art. 27(3).

I I 8. S. D. Bailey and S. Daws, The Procedure of the UN Security Council(I998), 250-6. 
Francisco, but that argument was lost. ${ }^{\text {II } 9}$ It has been revisited on numerous occasions by the UN Open Ended Working Group on the Question of Equitable Representation, which has unsuccessfully tackled the issue of reform of the Council, including the veto, since I994. ${ }^{\text {I20 }}$ There is no real reason why a permanent member should veto resolutions proposed under Chapter VI concerning the peaceful settlement of a dispute. The 'chain of events' theory (that a Chapter VI, or indeed a procedural, resolution might be the first step to a Chapter VII resolution) posited at Yalta was disreputable then and discredited now. ${ }^{\text {I2I }}$ The permanent members should agree to this. The real problem, however, is how to prevent the veto from operating to block legitimate Chapter VII resolutions.

Is it possible to avoid the position whereby a permanent member violates UN principles, thereby causing a threat to or breach of the peace itself, and then by the use of the veto prevents Council action or even condemnation? The answer to this question must, while the veto remains, be negative, for here the core of the veto power, which is to prevent enforcement action being taken against a permanent member (the negative facet of the veto), is represented. A more practical question is how the problem whereby a permanent member vetoes a Chapter VII resolution for illegitimate reasons that have nothing to do with the issue at hand and nothing to do with preventing enforcement action from being taken against it can be avoided.

A radical reform of the veto may seem a hopeless quest, given that amendment to the Charter, whether formal or informal, requires the consent of each permanent member. ${ }^{\mathrm{I} 22}$ Furthermore, to argue for more legal limitations would appear to be unrealistic, unless there are some mechanisms put in place for review of Security Council practice, including the use of the veto. It is difficult enough for the ICJ to undertake sporadic instances of review, never mind developing a system of review. Nevertheless, even without formal avenues of accountability, having clear legal limitations placed on the right of veto would enhance the authority of the Council, and would, within the current system whereby world opinion to a certain extent performs the function of review, allow the Assembly, states, organizations, and individuals to evaluate the legality of the exercise of the veto, as well as the consequences of its use. In practical terms it is unlikely that any Chapter VII action would be taken on the basis of a vetoed Council resolution, at least against a permanent member. But such defeated draft resolutions may be given legal effects, rather than having none, as is currently the case. ${ }^{\mathrm{I} 23}$ Confining the veto to proposed Chapter VII measures that affect the vital interests of a permanent member, or are contrary to the purposes and principles of the UN, or, as in the case of Iraq, are out of line with previous Council decisions, may be a way forward. ${ }^{\mathrm{I} 24}$ More specifically, the French proposal that

\footnotetext{
I I9. Russell and Muther, supra note 23, at 766.

I 20. J. Muller (ed.), Reforming the United Nations: The Quiet Revolution(200I), 62-6, I44-55.

I2 I. Bailey and Daws, supra note i 18 , at 240-2.

I22. UN Charter, Art. I08.

I23. Simma, supra note i 16 , at 514.

I24. Muller, supra note I20, at 65.
} 
there should be no veto of proposed clearly defined humanitarian interventions should be adopted. ${ }^{\mathrm{I} 25}$

While the above are meant by way of reform proposals or de lege ferenda, is it possible to identify existing legal principles that can be applied to the veto de lege lata? For instance would it be realistic to recognize that the principle of good faith applies to the veto? Recognizing the requirement that a veto must be exercised in good faith, a principle that Franck argues is applicable to Security Council activities, ${ }^{126}$ may serve to prevent the pernicious use of the veto. More realistically, it can be argued that its exercise as a right, power, or privilege granted to specific member states by the Charter must not violate the purposes and principles of the UN Charter. Just as Security Council action can be evaluated in terms of its compatibility with fundamental principles of international law as well as with the purposes and principles of the UN Charter, so, it can be argued, should the exercise of the veto. How many of the Cold War vetoes would have stood up well against these requirements? Putting good faith and the veto together in one sentence may be going too far; but testing the veto against the Security Council's primary purpose that of maintaining peace and security, is arguably legitimate. Furthermore, the veto should not be used to block action that is aimed at preventing or tackling violations of fundamental principles of international law.

Commentators have recognized that the veto is a 'very special power'I27 entailing the granting of 'extraordinary decision blocking competence'. ${ }^{228}$ It is suggested here that such competence should be judged against the constitutional parameters of the organization, and not merely by the ordinary rules governing voting. However, to argue that the veto is an institutional power or right, not merely the sovereign right of a handful of states, is contrary to the orthodoxy that clearly states that the veto vote like any vote in an international body is purely the exercise of a sovereign right. The orthodoxy is that 'the validity of the negative vote cannot be disputed'. ${ }^{\mathrm{I} 9}$

But times have changed, and if post-Cold War practice is considered, when the veto is being exercised with much more caution, it may be concluded that such a limitation is workable. There are hints that the pernicious use of the veto is being frowned on in the post-Cold War era, although the level of disapproval has not yet reached the stage of what could be called institutional opinio juris to the effect that such vetoes are unconstitutional. Mention can be made of the Chinese veto preventing the sending of military observers to Guatemala in I997 on the basis of Guatemala's perceived support for Taiwan. ${ }^{\text {I30 }}$ This was a short-lived blocking of action. More serious was the Chinese veto for similar reasons of the extension of the United Nations' preventive deployment of troops to Macedonia in February I999. ${ }^{\mathrm{I}}{ }^{\mathrm{I}} \mathrm{In}$ the Council chamber Macedonia stated that the Chinese veto was based

I25. J. Stromseth, 'Rethinking Humanitarian Intervention', in J. F. Holzgrefe and R. O. Keohane (eds.), Humanitarian Intervention: Ethical, Legal and Political Dilemmas (2003), 265.

I26. Franck, supra note 29, at 5I-3, 219-20.

I27. Simma, supra note i 6 , at 508.

I28. Claude, supra note I, 7 I.

I29. Simma, supra note i I6, at 5I4.

I30. SC 3730 th mtg, Io Jan. I 997.

I3I. See draft resolution UN Doc. S/I999/2 IO. 
on 'bilateral considerations' which 'we all consider to be in contradiction with the Charter'. Canada also criticized China for acting out of concern for 'bilateral concerns unrelated to UNPREDEP [UN Preventive Deployment Force]'. The United States regretted the use of the veto, stating that 'the overall interests of security in the region ... should be sufficiently compelling to outweigh other considerations'. Slovenia stated that the failure to extend UNPREDEP's mandate reinforced the need to reform the veto. China at first stated that the stability of Macedonia meant that there was no need to extend the mandate, but in response to criticisms later stated that the accusations were unfounded and that 'deciding on the merits of an issue was the sovereign right of every State'. ${ }^{132}$

Both of these Chinese vetoes were based on grounds unrelated to peace and security and could be said to be instances of the exercise of power that were contrary to the purposes of the United Nations as regards the maintenance of peace and security. The veto of UNPREDEP in Macedonia, a rare instance of UN preventive peacekeeping, was shown to be disastrous as that country suffered a spillover of violence from the Kosovo crisis, necessitating belated reactive military deployment by NATO in September 200I. The threatened US veto in July 2002 of an extension of the mandate of the UN mission in Bosnia unless immunity from the ICC was granted to its peacekeepers could also be viewed as problematic. ${ }^{\text {I33 }}$ The desire of the United States to protect its personnel from prosecution ${ }^{\mathrm{I} 34}$ seemed to be unconnected to the peace and security of Bosnia, while the threat of the veto itself engendered a potential security crisis in that country.

The Russian veto on 2 I April 2004 of a new force to replace the UN Peace-Keeping Force in Cyprus (UNFICYP) to guarantee security on the island in the event of the Greek and Turkish Cypriots voting for the UN unification plan on 24 April seemed to be on 'technical' grounds rather than on matters of substance. The technical matters referred to by Russia seem mostly to have related to the 'precipitous' manner in which the draft had been prepared by the United States and the United Kingdom and negotiated informally. ${ }^{\mathrm{I}} 35$ Although criticism of the Russian veto was muted in the Council, probably in the hope that it would not undermine efforts to gain a positive vote in the referenda, it must be doubted whether such a veto was compatible with the purposes and principles of the UN Charter. Whether this failure by the Council sent the wrong signal to the Greek Cypriots, who most wanted a security guarantee, ${ }^{136}$ is impossible to gauge, although the fact is that they voted against the plan on 24 April, thereby preventing the best chance for a solution to the island's division since the Turkish invasion of $1974 .^{\text {I37 }}$

\footnotetext{
I32. SC 3982nd mtg, 25 Feb. I999.

I33. SC 4568th mtg, ro July 2002.

I34. Achieved in SC Res. I422, I 2 July 2002.

I35. SC 4947th mtg, 2 I April 2004. UN Doc. S/2004/3I3, 2 I April 2004.

I36. See comments by United States and France in SC 4947th mtg, 2 I April 2004. 'UN Plan on Cyprus Unity Receives Two Major Setbacks', International Herald Tribune, 23 April 2004, 3.

I37. The exceptional subsidiary powers of the General Assembly should not lightly be invoked in these situations, but it is arguable that, in the case of the pernicious vetoes of the UN Preventive Force in Macedonia in I999 by China and of the replacement for the UN Force in Cyprus by Russia in 2004, that competence should have been utilized, just as it was in 1956 to create first significant peacekeeping force in the Middle East, following
} 
However, the limitation on the veto imposed by the UN's purposes and principles will only catch the most obvious abuses. Of course a balance must be achieved between limiting the exercise of the veto and its positive aspect - that it ensures that Council action has the support of the most powerful members. As the debates in the Working Group show, the veto is unlikely to be given up by members of the $\mathrm{P}_{5}$ but they may be willing, if they wish the Security Council containing a veto power to have a future role, to subject it to legal standards that would allow for some form of accountability for its use. As with the occasional Council resolution that does not fulfil the purposes of the UN Charter but only furthers the agenda of one of the $\mathrm{P}_{5}$, the occasional casting of a veto purely out of national interest that prevents the Council fulfilling its primary function must be subject to legal standards and accountability. Whereas institutional law has reached the stage of recognizing that such a resolution can be ultra vires though there are no effective means of enforcing such a conclusion, it has not yet applied the same standards to the capricious use of the veto. Such gaping legal holes in the Council's constitution undermine its authority.

\section{Conclusion}

Although it was the veto that largely prevented Council action during the Cold War, the recent Iraq crisis is perhaps misleading if it suggests that more recent Council inaction is mainly due to the veto. ${ }^{\mathrm{I}} 8$ The last decade, when there has been a reduction in the use of the veto, has brought to the fore the selectivity of Council action. There has been an unwillingness by member states to initiate or to contribute to effective executive action or effective behind-the-scenes diplomacy in certain conflicts, for example in Rwanda in I 994. The inhumane conflict in the Congo is the current test of the Council's resolve to deal with conflicts that do not concern its permanent membership. While the French and British contributed to a force sent to the north-east of the Congo in June 2003 under a Security Council mandate, ${ }^{\mathrm{I}} 39$ its size $(\mathrm{I}, 400)$ suggests a continued lack of real commitment. This is borne out by a leaked French military briefing document obtained by the Guardian newspaper that was pessimistic as to the value of the force, stating that the 'operation is politically and militarily high risk; very sensitive and complex. France has no specific interest in the area except solidarity with the international community.'.40 The token gesture to solidarity speaks volumes. However, a more encouraging sign is the French and US operation in Haiti in March 2004, operating under a Chapter VII mandate. ${ }^{\text {I4I }}$

Clearly the selectivity of the Council is a major issue as regards its continued credibility. Although there is a balance to be achieved in the Council between

the French and British vetoes in the Council. The Assembly's power to mandate peacekeeping forces was recognized by the International Court in I962 - see Certain Expenses of the United Nations, [1962] ICJ Rep. I62.

138. But see US vetoes of drafts on aspects of the Palestinian issue - SC 3765th mtg, 2I March I997; SC 4828th mtg, I6 Sept. 2003.

I39. SC Res. I484, 30 May 2003.

I40. Guardian Weekly, I 2-I8 June 2003, 4.

I4I. SC Res. I529, 29 Feb. 2004. 
the executive and diplomatic functions, the latter is not to be taken as an excuse for inaction. Indeed, if the lack of action is not because of the veto but due to indifference, to collective inertia rather than genuine disagreement, then the Council is failing in both its functions. This should be remedied by each permanent member taking its Council responsibility for international peace and security seriously, rather than each being primarily concerned with threats to its own security. It is argued here that the Council's primary responsibility for peace and security is the responsibility of each permanent member. It is often recognized, not least in the rhetoric of the permanent members, that the special position of permanent membership entails duties; there needs to be specification of those duties. For instance, in parliamentary debates about the sending of UK troops to eastern Zaïre in I996 as part of a later aborted UN-authorized Chapter VII multinational operation, ${ }^{\text {I }}{ }^{42}$ the UK Secretary of State for Defence stated,

The House will rightly ask why Britain should become involved in a place far from our country and where no vital interest is engaged. It is because we are a civilised nation. We can see that people are about to die in their thousands, and we are one of the few nations on earth that has the military capability to help at least some of them. We recognise our humanitarian obligation. We take pride in our permanent membership of the United Nations Security Council, but it carries with it clear duties. ${ }^{\text {I43 }}$

An inability by the current $\mathrm{P}_{5}$ to accept their responsibility within the Security Council, either at an executive or a diplomatic level, in relation to threats to and breaches of the peace wherever they occur, may well be the best justification for expanding the permanent membership to include states that can bring initiatives and resources to the Council for dealing with conflicts in Africa and other neglected areas of the world. It is also a further justification for again recognizing and utilizing the exceptional subsidiary responsibility of the General Assembly.

Has the Iraq crisis of 2003 fatally undermined the authority of the Council? Although it seems to be business as usual after the adoption of Resolutions I 483 (2003) and I546 (2004) with regard to 'post-conflict' Iraq, it may be doubted whether the Council's authority could survive another crisis of the type witnessed in Kosovo and Iraq, when it successfully fulfilled neither its executive nor its diplomatic functions. Without change, that authority will be much reduced and there will be a 'marginalization of the Council on matters of peace and security'. ${ }^{44}$ With change - which has to be driven by the permanent members limiting their right of veto, recognizing their Council responsibilities for peace wherever it is ruptured, and proposing and interpreting resolutions that accord with the Charter, fundamental principles of international law, and the will of the Council - it stands a chance of performing a central role in maintaining peace and securing justice.

I42. SC Res. I078, 9 Nov. I996.

I43. 285 HC Deb., 6th Ser. I 4 Nov. I996, cols. 487-9 (Michael Portillo).

I44. Ratner, supra note 4I, at 603. 